\section{Studia}

z Filologii Polskiej
i Słowiańskiej

DOI: $10.11649 /$ sfps.2168
Studia z Filologii Polskiej i Słowiańskiej, 56

Warszawa 2021

Article No. 2168

Citation:

Богдан, С. К., \& Тарасюк, Т. М. (2021). Лексичний регулятив дім в епістолярних текстах Лесі Українки й посланнях Андрея Шептицького. Studia z Filologii Polskiej i Słowiańskiej, 56, Article 2168. https://doi.org/10.11649/sfps.2168

Bohdan, S. K., \& Tarasiuk, T. M. (2021). Leksychnyĭ rehuliatyv dim v epistoliarnykh tekstakh Lesi Ukraïnky ĭ poslanniakh Andreia Sheptyts'koho. Studia z Filologii Polskiej i Słowiańskiej, 56, Article 2168. https://doi.org/10.11649/sfps.2168

Світлана К. Богдан

(Волинський національний університет імені Лесі Українки) Тетяна М. Тарасюк

(Волинський національний університет імені Лесі Українки)

\title{
Лексичний регулятив дім в епістолярних текстах Лесі Українки й посланнях Андрея Шептицького
}

Однією з диференційних ознак будь-якого тексту лінгвісти справедливо вважають регулятивність використання різних мовних одиниць, розглядаючи їі здебільшого як «системну ознаку, яка полягає в [...] здатності „керувати“ пізнавальною діяльністю читача» (Болотнова, 2006, с. 328). Під поняттям регулятивні засоби (регулятиви, регулятеми) зазвичай розуміють лінгвальні або позалінгвальні елементи, які функціонують у конкретній текстовій системі, відображають авторський світогляд і творчий задум, стимулюють мовно-мисленнєву діяльність читача й керують сприйняттям тексту реципієнтом (Галаур, 2017, с. 119). Визначальним критерієм статусу регулятивності є важливість цих одиниць у процесі пізнання особливостей не так відображення, як конструювання національного та

This is an Open Access article distributed under the terms of the Creative Commons Attribution 3.0 PL License (creativecommons.org/licenses/by/3.0/pl/), which permits redistribution, commercial and non-commercial, provided that the article is properly cited. (C) The Author(s) 2021.

Publisher: Institute of Slavic Studies, Polish Academy of Sciences

[Wydawca: Instytut Slawistyki Polskiej Akademii Nauk] 
індивідуального мовопростору з огляду на те, що, як слушно стверджує Станіслав Гайда, «Нація і стиль [...] представляють собою концептуально-(ідеологічно)-дискурсивні конструкти» (Гайда, 2016, с. 35). Власне тому кожна національна мова й мова окремих особистостей, крім експлікації типологічних та спільних для інших етносів регулятивних мовних одиниць, має й особливі риси актуалізації концептуального простору.

Узвичаєно вирізняють власне лінгвальні регулятиви й екстралінгвальні (Болотнова, 2006, с. 328). Лінгвальні регулятиви об'єднують ритміко-звукові, лексичні, морфологічні, словотвірні та синтаксичні одиниці, а екстралінгвальні - композиційні, графічні та логічні (Болотнова, 2006, c. 329). За здатністю репрезентувати мікро- чи макроціль у межах комунікативної стратегії тексту розрізняють регулятиви-локативи й регулятиви-концепти (Болотнова, 2011, с. 34).

До найбільш увиразнених, цілком передбачувано, належать різноманітні лексичні регулятиви, що мають концептуальний вимір, а 3-поміж них ті, які належать до архетипних понять у будь-якій культурі й будьякій національній мові. Одним із найдавніших і типових 3-поміж них різні дослідники цілком слушно вважають лексему дім, яка відзначається насамперед такими основними диференційними параметрами: частотністю вживання, традиційністю використання в різних функційних стилях, символічністю й безпосередніми стійкими зв'язками з культурою певного народу за наявності інваріантних ознак у кожній національній мові, а також різноманітними семантичними трансформаціями, що слугують елементом вияву динаміки в семантико-стилістичній площині цього номена.

Саме цим мотивована, очевидно, постійна увага дослідників (передусім - мовознавців і літературознавців) щодо вивчення регулятива дім у різних аспектах і на матеріалі різних мов. Предметом найбільшого постійного зацікавлення слугують, зокрема, такі аспекти функціонування лексеми diм: її концептуальний статус у різних національних мовах (як особливий сегмент українського мовного простору (Яворская, 2004), як засіб найменування релігійних споруд в українській мові (Піддубна, 2005), як екзистенціал української культури (Ковальчук, 2016); своєрідність актуалізації в польській (Лебеденко \& Василенко, 2016) і в англійській мовній картині світу (Шевченко \& Давиденко, 2012), не менш часто в порівняльному контексті: в українській, російській і польських мовах (Лебеденко \& Василенко, 2013), в американській, французькій, польській 
та українській лінгвокультурах (Андрусів, б.р.)); експлікація в різних жанрах і функційних стилях (Антонюк, 2012; Черкашина, 2016); особливості семантичного простору цього концепту в системі певного ідіостилю (у поетичних та драматургічних текстах Лесі Українки (Кочерга, 2008), у романі Пантелеймона Куліша Чорна рада (Янковська, 2011), в ідіолекті Валерія Шевчука (Монахова, 2010)) тощо.

Дослідники одностайно стверджують концептуальний статус цієї лексеми в мовній парадигмі різних етносів, акцентуючи увагу на властивій універсальності використання, національній специфіці й наявності індивідуальних елементів у їі семантичній структурі, та визначають іiї здебільшого як етнічний лінгвокультурний концепт (Андрусів, б.р.; Воркачев, 2007; Карасик \& Сышкин, 2011), архетиповий / культурний етносимвол (Пашкова, 2014), етнокультурний концепт (Лебеденко \& Василенко, 2016), ключовий концепт ідіостилю (Монахова, 2010) тощо. На нашу думку, правомірно кваліфікувати його як домінувальний лексичний регулятив у будь-якому ідіостилі, що має національно окреслений лінгвокультурологічний статус із огляду на визначальність у формуванні й індивідуальної, й національно-мовної картин світу.

Функційна різнорідність використання цього регулятива, хоч і очевидна реальність, однак дотепер, як бачимо, обмежена в основному вивченням його концептуальної репрезентації в художніх текстах і як слова-стимулу в асоціативних експериментах серед студентів різних етнічних спільнот. Епістолярні тексти, які гіпотетично жодним чином не можуть оминути використання регулятива дім, залишаються дотепер на периферії наукових досліджень. Цим і мотивований вибір матеріалу нашого дослідження - листи Лесі Українки (Українка, 2016, 2017, 2018) та послання Андрея Шептицького (Шептицький, 2007, 2009, 2010), які допоможуть нам (принаймні частково) пізнати специфіку форм і способів його використання в українській мовній парадигмі кінця XIX - початку XX ст. і особливості вербальної експлікації семантичного простору концепту дім в ідіостилістичних системах двох видатних мовних особистостей цього періоду.

Передусім зауважимо: в українській мовній традиції цей регулятив, навіть за побіжних спостережень корпусів українських текстів (Генеральний регіонально анотований корпус української мови, б.р.; Корпус украӥнської мови, б.р.; Український національний лінгвістичний корпус, б.р.), має також (як і в інших мовах) статус ядерного концепту й актуалізований у трьох 
основних ключових лексемах: дім, дом і дома (хронологічно первинний варіанти - дом / домъ). Українські лексикографічні джерела, подібно до інших мов, узвичаєно кваліфікують першу й другу номінатеми як основні («Дім, до́му, м. Домъ. Згода дім будує, а незгода руйнує» (Грінченко, 1907, с. 392); «Дім, дому, чол. 1. Будівля, признач. для житла або для розміщення різних установ; будинок. 2. Приміщення, в якому живуть люди; житло. 3. Приміщення, люди, що в ньому живуть, та їх господарство. 4. рідко. Монархи одного роду, що послідовно замінювали один одного» (Білодід, 1971, с. 306); «Дом, му, м. = Дім» (Грінченко, 1907, с. 418)), хоч закономірно давнішою з огляду на фіксацію в пам’ятках є лексема дом («Домъ, дом, домь ч. (135) 1. Дім, житло, оселя (18); 2. (будівля) дім, будинок (36); 3. Садиба (6); 4. (феодальна земельна маєтність) вотчина (69); 5. Храм, церква (5); 6. (династія) дім, рід (1)» (Гумецька, 1977, с. 317)). Лексему дома здебільшого визначають як рідковживану або радше як одиницю прислівникову, на противагу первинному граматичному виміру - іменниковому, порівняймо хоча б їхнє тлумачення в словнику Грінченка та в академічному словнику української мови: «I. До́ма, ми ж. = Дім. Своя дома. [...] II. До́ма, нар. Дома. Чом не хочеш ти робити і дома сидіти» (Грінченко, 1907, с. 418) і «До́ма. 1. присл. Те саме, що вдома. 2. ім. дома, и, жін., розм. Те саме, що домівка» (Білодід, 1971, с. 361).

В ідіолектах Лесі Українки та Андрея Шептицького фіксуємо (із різною частотністю використання) лише кілька лексем синонімічного словотвірного ряду, спільних для слововжитку обох комунікантів, - дім, доми́ (мн. від дім), домі́ка, до́ма (присл.), удо́ма / вдо́ма, домі́в (присл.), дома́шній, дома́шні (імен., прикм.), а до́мик, домо́чок, до́ма (імен.), доми́к (рос. мовою) лише в епістолярному мовленні Лесі Українки, дімо́к, домо́вий (імен., прикм.), домі́вники́ властиві посланням Андрея Шептицького. У їхньому індивідуальному мовленні наявне також використання подібних юкстапозитів хата-дома (в Лесі Українки) і хата-домівка (в Андрея Шептицького). Домінувальною і для епістолярної комунікації, і для текстів послань можна вважати найчастотнішу лексему дім. Лексема дом відсутня в ідіолекті і Лесі Українки, і Андрея Шептицького, яка, очевидно, вже була анормативом у мовленні українців кінця XIX - початку XX ст. Іменникова номінація до́мa, як і передбачалося, належить до ядерних лише в епістолярних текстах Лесі Українки.

Принагідно зауважимо, що в аналізованих текстах обох авторів фіксовано також не менш частотне вживання лексеми хата (історично, 
за спостереженнями мовознавців, пізніша номінація житла порівняно з дім / дома - XVI ст. (Пашкова, 2014, с. 121)). Порівняльно-зіставний аналіз контекстів їхнього вживання дає можливість стверджувати насамперед різність використання цих лексем 3 огляду на традиційну диференціацію значень в узусі української мови, а тому й неможливість абсолютної взаємозаміни, порівняймо: молитовний дім (а не хата) / diм молитви (а не хата); Ласкаво запрошуємо до хати! (а не до дому); Мир Вашому дому! (а не хаті) тощо.

Лексеми дім і хата мовознавці здебільшого визначають як «двоядерні елементи» концепту житло (Пашкова, 2014, с. 127). Дихотомія дім / хата властива різним національним мовам, скажімо, англійській (home / house), російській (дом / изба) тощо. Водночас $є$ мови, які мають одне найменування цього поняття, як-от французька (maison). Ці дві лексеми утворюють дублетний концепт дім. Однак у семантичній структурі цих лексем існують як схожі, так і відмінні ознаки. До спільних ознак належить здебільшого вказівка на місцезнаходження людини, тобто iї помешкання, житло, оселю. За спостереженнями Ірини Шевченко й Інни Давиденко, в англійській мовній картині світу концепт house / hoте двоєдиний: перша лексема позначає зовнішню оболонку, а друга іiї вміст (Шевченко \& Давиденко, 2012). Натомість паремійний матеріал дає підстави Надії Пашковій висновувати, що «два ядра українського концепту здиференційовані за іншими ознаками - „житло взагалі“ та „сільське житло“, у якому виявляється історична специфічність української ментальності» (Пашкова, 2014, с. 127).

Дослідники національної специфіки концепту дім у польській мові слушно зауважують, що «поняттєвий компонент концепту ДІМ включає в себе сприйняття дому двовимірно: на фізичному рівні (як матеріального об’єкта, що має свої структурні особливості) й метафізичному (як олюдненого простору). Ціннісний компонент цього концепту встановлює його культурний статус» (Лебеденко \& Василенко, 2016, с. 100). А тому вчені вважають, що і його концептуальне поле фокусує насамперед смисли, які «спочатку відштовхуються від конкретних фізичних реалій, а потім переосмислюються й набувають образно-символічного звучання. Синкретизм зумовлює їх морально-духове сприйняття. Простір дому не стільки становить пасивне середовище, скільки достатньою мірою концептуально організоване органічне поле» (Лебеденко \& Василенко, 2016, сс. 100-101). Щоправда, всупереч теоретичному постулуванню про первинність 
фізичного рівня сприйняття концепту дім у польській ментальності, Юлія Лебеденко і Яна Василенко стверджують, що асоціативне поле цього концепту органічно поєднує такі семантико-тематичні єдності: дім - тепло (психологічне) - родина - родинні свята - камін (тепло фізичне) - собака (охоронець дому) (Лебеденко \& Василенко, 2016, с. 101), таким чином визнаючи мимохіть, що насправді саме духовий складник, а не матеріальний покладений в основу польської картини світу. Подібну семантичну структуру в мовленні українців має не лише лексема $\partial i$, а й дома, уживана здебільшого в поліських говірках, зокрема на Волинському Поліссі. Для поліщуків, за нашими багатолітніми експедиційними спостереженнями, дома - це насамперед - рідна, батьківська оселя (найвагомішими смисловими домінантами якої є родина, атмосфера дому, затишок), рідне подвір'я, сад. Дома - це водночас і рідне село, рідний край, край дитинства, це мала батьківщина, це Україна.

Для українців дім і хата, як свідчить корпус текстів української мови, утворюють насамперед виразну опозицію духового й матеріального, а тому синонімом номена хата частіше є саме лексеми будинок, помешкання (і її різноманітні видові назви - кам'яниця, землянка, хижа, хижка, халупа), тобто ті, що співвіднесені насамперед із будівлею. До того ж, у словниках нерідко зазначають - як диференційні ознаки - маркери сільський і одноповерховий (будинок) (Жайворонок, 2006), а це зумовлює зміну її статусу в сприйнятті сучасної молоді («хата, - за твердженням Надії Пашкової, - відходить на народно-пісенну етнокультурну периферію» (Пашкова, 2014, с. 127). А тому навряд чи правомірно вважати лексему $x a m a$ абсолютним синонімом щодо дому в українській мовній традиції. Ствердженням диференційованого вживання цих лексем в українській мові слугує також слововжиток Лесі Українки та Андрея Шептицького. Одним із переконливих контекстів розрізнення цих понять слугує, зокрема, лист Лесі Українки (10 (23).Х.1902) зі Львова до матері: «Була y О[льги] Ф[едорівни] (Ольги Франко. - прим.) (гроші віддала). Далеко дуже той дім (тут і далі вирізнення в текстах Лесі Українки й Андрея Шептицького наші. - С. Б., Т. Т.), аж за містом. Місие гарне і хата нічого собі (я, звісно, сужу по виду, а чи практично збудовано, того не знаю), вони вже там живуть [...], ледве устроїлись, в хатах дуже порожньо». Як бачимо, лексема дім у цьому фрагменті - виразно родове поняття на противагу хаті, яку вжито в значенні ‘будівля’ і ‘кімната’. 
Концепт дім в аналізованих текстах Андрея Шептицького вжито здебільшого не як помешкання, а як особистісний прихисток людини, духовний вимір родини, тобто як елемент типологічної тріади дім - людина - Бог / cвim. Натомість у мовотворчості Лесі Українки таку функцію виконує лексема дома, тоді як дім у їі текстах актуалізовано переважно в значенні 'будівля', 'житло'. Спостережено: концепт дім як духова субстанція належить до визначальних семантичних вимірів в ідіостилі обох комунікантів.

Типологічними для ідіолектів обох мовних особистостей можна вважати аналітичні найменування з опорною лексемою дім. Це передусім атрибутивні словосполучення, які визначають специфіку власне світського, побутового відображення концепту дім у Лесі Українки й релігійного - в Андрея Шептицького. В епістолярних текстах Лесі Українки атрибутиви характеризують дім здебільшого за ознаками при-

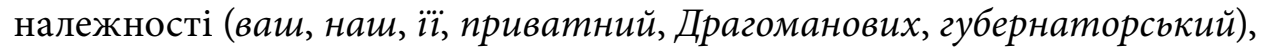
просторового розміщення (той, в Зеленому Гаю), якісними параметрами (новиц̆, великий, чужий), тобто переважальна семантика дому, домівки як матеріальної субстанції. У посланнях Андрея Шептицького, крім подібних атрибутивів приналежності (свій, мій, твій, ващі, родинний), зафіксовано також стилістично диференційовані означення мешкальні, капітульний, ближнього, священика / священичий, служебниць, монарший, митрополичиц̆, чернечі, парохіяльний, Володаря.

В Андрея Шептицького лексема дім / доми має подібні атрибутивні характеристики (порівняймо: цъілй, увесь, кожний, поодинокі), однак найвиразнішою диференційною ідіостильовою ознакою можна вважати той факт, що в його текстах послідовно актуалізовано виразну опозицію дім земний - дім небесниц̆, яку експліковано здебільшого аналітичним найменуванням дім Божий / Божий дім (на землі) (фіксовано обидва варіанти: i пре- і постпозитивний) і власне небесна оселя Отця нашого Бога - npaвдuвий Божий храм, Господній дім, вічне изарство Боже. А тому передбачувано найуживаніші атрибутивні словосполучення - це аналітичні назви різних релігійних споруд. До речі, раніше щодо дому Божого в значенні «місце, помешкання для молитви» вживали назву дім молитви / молитовний дім (первинно - Єрусалимський храм і молитовні будинки іудеїв), пізніше перенесене й на християнські храми (Піддубна, 2005, сс. 257-258).

Перифраз храм / церква - Божий дім належить до семантико-стильових домінант послань митрополита, наприклад: Якби я Вас спитав, що значить те слово «церков», то кождий із Вас знав би сказати, щь иерков - се Божий 
дім; тому, вступаючи в церков, ми поклони перед Богом били, бо Всевишній Бог неначе в тім святім домі жиє (Шептицький, 2007, с. 149).

Привертає увагу й те, що дім земний у текстах його послань семантично двовимірний: це не лише храм, але й будинок кожної людини, якщо в ньому присутній Святий Дух, якщо в господаря й родини пріоритетними є заповіді духові, а не матеріальні цінності (Icyc Христос має на думиі світлицю нашого серия, бо ж говорить до людей убогих, простих, і ледви чи з його слухачів були люди, щзо мали в домі світлиці, в яких могли замикатися, а зрештою, немислимо, щоби Христос говорив то лишень до людей, щьо мають досить велике мешкання, щьби в якійсь кімнаті самому замикатися (Шептицький, 2009, с. 756)). У такому домі також «живе», «гостює» Господь: Тим часом бажає він хоч листом зайти в кожну хату та поговорити про дім Божий, церкву. Вона є образом правдивої церкви: неба й світу (Шептицький, 2007, с. 866). В останньому контексті виразно простежуємо імплікацію інтертекстуального виміру Святого Письма, зокрема відомого афоризму мій дім - мій храм, що знайшов, як відомо, актуалізацію і в одному з поетичних текстів Лесі Українки, порівняймо: Ми навіть власної не маєм хати, / усе одкрите в нас тюремним ключарам. / Не нам, обідраним невільникам, казати / Речення гордеє: «Мій дом - мій храм» (поезія Товаришці на спомин).

Дім небесний в Андрея Шептицького, релевантно до релігійних канонів, - це насамперед дім вічного буття й прихистку людської душі: Блаженством видається душі мешкати в Господньому домі й Бога навіки хвалити (Шептицький, 2010, с. 655).

Як бачимо, вживання лексеми дім в ідіолекті Андрея Шептицького має виразний функційно диференційований статус і завжди позначений високою урочистою стилістикою експлікації.

Для обох мовців дім - це своєрідна межа рідного й чужого простору, вербалізована в узусі української мови типовим бінарним опозитом рідний - чужий дім. Щоправда, саме такі словосполучення відсутні в слововжитку обох мовців. Натомість семантика рідного дому експлікована в ідіолекті Андрея Шептицького атрибутивними сполуками батьківський дім (рідко вжито як синонім - рідна хата), дім Батька, вітцівський дім / дім вітияя (в узусі, як відомо, поширене ще й найменування отчий дім). Для митрополита батьківський дім - це і реальна рідна земна оселя, і водночас - оселя небесна. Актуалізація двоєдиних семантичних вимірів цього словосполучення цілком передбачувано майже завжди експлікує відо- 
мий бібліїзм блудний син (Лука, 16: 20-21) (синонім - марнотратний син, узвичаєна номінація «людини, яка розкаялася, усвідомила свої помилки» (Коваль, 2001, с. 248)), який неминуче (після мандрувань, поневірянь, зневір, падінь) таки повертається до рідного дому, що є для нього насамперед вмістилищем прихистку, розради й духового зцілення:

Коротиу дорогу до батьківської хати має чоловік, що вправді відступив, своє майно стратив, віддав себе на службу в чужому краю і пасе безроги пристрастей, бо йому ще тишилася гадка, що існує дім Батька, що той Батько ємилосердний, що є поворот можливий та лищилося щось із бажання бодай того добра, що його зазнавав у батьківській хаті (Шептицький 2009, с. 1014).

А тому дім у таких контекстах гармонійно поєднаний з іншим архетипним концептом української ментальності - дорогою. За Шептицьким, дорога до батьківського дому - це дорога прощення, дорога очищення:

Щасливий той, кому Бог дає нагоду покути, бо наші терпіння є і покутою за наші гріхи. Не раз вони є потрібні до одержання прощення від намого Батька, Бога. Через ті терпіння наша душа, ведена Божою благодаттю, іде дорогами блудного сина, що вертає до батьківського дому (Шептицький, 2009, с. 123).

А тому вона, на переконання митрополита, семантично релевантна дорозі до сповіді, порівняймо:

А комуж не треба прощення провин від милосердного Отия? Хто жн не є блудним сином? Тому, йдучи до сповіді так, як блудний син до дому милосердного Отия, й бажаючи, щзб Він нас як милосердний Отеиь прийняв і простив гріхи, мусимо бодай у дусі помиритися з ворогами (Шептицький, 2009, с. 334).

Образ рідного дому в Лесі Українки вербалізовано за посередництвом іншої лексеми - дома. Дома для неї - це передусім село Колодяжне на Волині, де вона мешкала найдовше з усіх українських міст і сіл. Дома - це і рідна земля, це Україна. Дома - це найбажаніший локус її перебування, що й пояснює частотність конструкцій саме просторової семантики з цією лексемою в її епістолярії.

За нашими спостереженнями, це слово для всіх Косачів було елементом їхнього епістолярного спілкування, а отже, найімовірніше, і повсякденного родинного. Запозичення цієї лексеми з говіркового мовлення й актуалізація в активному словнику родини - безперечно «колодяжанський» період. Невипадково й актуалізація її в Косачівському мовленні припадає саме на час переїзду родини в Колодяжне, а семантична струк- 
тура цієї лексеми має виразну територіальну ознаку. У кореспонденції попереднього періоду вона має значно частіше прислівниковий статус. Порівняймо, зокрема, іiї вживання в індивідуальному епістолярному мовленні Лесі Українки та її брата, Михайла Косача:

От я і дома! Дивно се якось отак перелетіти швидко з Відня на Волинь, аж навіть у голові якийсь хаос повстає з тих враженнів, думок, порівняннів, тепер удома мені все якимсь иншим здається, все здається таке як і перше було, однак на всьому немов якась инша барва лежить (до Косача М. П., Колодяжне, кінець березня 1891 р.)

і Леопарді і альбом я тобі одразуж вишлю, як приїду до доми. Дома я мислю бути числа 20-го, напевне (до сестри Лесі, 14 іюля 1891 р. Полонне).

Вживаючи цю лексему поза звичним «колодяжанським» контекстом, Леся Українка послідовно використовує графічний маркер - лапки, імплікуючи, очевидно, у таких випадках відсутність властивої для цієї номінації семи 'рідна', як-от у листі з Сан-Ремо: Взагалі проти Австрії мені Італія, а надто Сан Ремо здається «дома», - тут і тепліше і привітніше і природа і люде. Всі мене прийняли як рідну (до родини Косачів, Сан-Ремо, 20.X (2.XI).1902).

У листах Лесі Українки зафіксовано також використання прецедентних текстів для вербалізації ширшого значення рідного дому - України, фіксованого українськими фольклорними текстами: тихі води, ясні зорі (частіше вжито усічений варіант - тихі води) і тихі води, мир хрещений: Дуже мені вже хочеться до дому, до тебе, «на тихі води, на ясні зорі», все здається, що там скоріш минеться моя втома і сей змінливий стан то кипіння, то замерзання, в якому я тепер постійно пробуваю (до Косач О. П. (матері), Одеса, 2 (14).VI.1898).

Спільними лексико-семантичними константами рідного дому в обох комунікантів виступає семантика повернення й передусім вектор руху - до дому / до доми й локус перебування в ньому, репрезентований прислівниковими лексемами удома / вдома і дома (лише в слововжитку Лесі Українки).

Семантика повернення додому експлікована узвичаєними дієслівними та іменниковими маркерами, 3-поміж яких за кількісними параметрами вирізняються лексеми: вернути, вертатись, вертатиму, вернеться, повернутись, вертаючи, поворіт, на поворіт, поворот; спішитися, рушать, дісталась, хочеться, поїду, приїхати / приїхать, поїхати на поправку, не їздли - у Лесі Українки й вертався, верне, відпроваджувати, відсилати, зближався, поворот до дому - в Андрея Шептицького. 
Спільним для них обох $є$ використання говіркового прислівника домів, щоправда, з різною частотністю вживання (послідовно - в посланні До моїх любих гуиулів Андрея Шептицького, але не тільки в ньому, a і в інших текстах, що слугує ствердженням його визначальності в ідіолекті митрополита). А отже, цей прислівник використано передусім як засіб стилістичного увиразнення й зменшення комунікативної дистанції в спілкуванні з потенційним адресатом, що належать до особливого говіркового середовища. В ідіолекті митрополита зафіксовані такі словосполучення з цією опорною лексемою: вернути домів, вертають домів, несе домів, заганяти домів, не вертав домів (Щось з Христових страстей тут лишилося. I кожний паломник стає свідком тих споминів, тих передань, щоб, вернувши домів, ставати і свідком Христової науки (Шептицький, 2007, с. 597)). Один раз їі фіксовано також у листі Лесі Українки до Ольги Кобилянської, порівняймо: Се я вже їу домів! Таки вже й час [...] (Севастополь, 27.V (9.VI).1911)) з огляду на те, що цей діалектизм належить до гуцульського мовопростору.

Типологічними для релігійної комунікації можна вважати й атрибутивні словосполучення, утворені різними типами зв'язку (узгодження, керування), присвійність у яких експлікована іменами біблійних осіб, що характерно передусім для ідіолекту Андрея Шептицького: дім - Ізраїлевий, Давидовий, Закхея, Лазаря, Анни, Захарія, Каяфи, Симона. Контексти їхнього функціонування в посланнях закономірно мають інтертекстуальний вияв і $\epsilon$ елементом однієї з диференційних ознак семантичної організації текстів послань - гетерогенності. Актуалізація таких елементів здійснюється за допомогою як прямого, так і опосередкованого цитування: Тому звичайно оповідання св[ятого] Луки (7, 37-50) про навернення явногрішниці в домі Симона пристосовують до неї (Шептицький, 2009, с. 490) і Коли до того додамо і ту незвичайну похвалу, яку Христос сказав Марії, сестрі Лазаря, в домі Симона прокаженого: «Де-небудь буде проповідане ие Євангеліє, по всьому світу скажеться і про те, що вона вчинила, на ї̈̈ пам'ятку» (Мт. 26, 13) (Шептицький, 2009, с. 492).

Одне з таких словосполучень використано обома авторами - дім Ізраїлевий (в Андрея Шептицького) і дім Ізраеля (в Лесі Українки). У посланнях його актуалізовано посередництвом цитування біблійного тексту для аргументації: Першим і найважнішим завданням душпастиря - ие шукати загубленої овечки, й перший приказ Христа, даний апостолам, ие «йдіть до овець, щз загинули з дому Ізрайлевого» $(\mathrm{Mm.} \mathrm{10,} \mathrm{6)} \mathrm{(Шеп-}$ 
тицький, 2009, с. 218). У Лесі Українки цей бібліїзм вжито в контексті міркувань про долю Рахіль, образ якої став основою одного з її творів:

Я питу сеє все, а в думці все одбивається: «Рахіль плаче і не хоче потішитись по дітях своїх, бо їх немає». [...] Хто була та Рахіль? Може якась невідома жінка часів Ирода? а може «будівниия дому Ізраеля»? Які були ї діти? Які були б вони, коли б виросли здорові? Чи памятали б їх люде досі, їх і матір? ічим би їх помянули нащадки? Хто знає [...] але тепер вони безсмертні, бо туга їх матері безсмертна, а вони живуть в ї тузі (до Франка I. Я., СанРемо, 31.XII.1902 (13.I.1903)).

Зауважмо, що в цьому фрагменті адресантка майже дослівно експлікує текст Євангелія від Матвея, порівняймо: «Чутно крик в Рамі, великий плач і скарга, Рахіль плаче по дітях своїх і не може потішитись, бо їх немає» (Єв. Матв. 2, 1). Цей факт засвідчує водночас їі добрі знання біблійних текстів. До того ж, Леся Українка використала ці рядки як епіграф до твору Прокляття Рахілі (1898).

Лексему дім у посланнях митрополита нерідко актуалізовано в цитатах зі Святого Письма, що загалом можна вважати однією з диференційних ознак семантико-стильової організації релігійних текстів, наприклад: Але при тім повторює їм єще той приказ Божого Закону: не пожадай жени ближнього твого, ані єго дому, ані поля, ані вола, ані осла, ані жадної річи, котра єсть єго власністю (Втор. 5, 22-9 і 10 заповідь Божа) (Шептицький, 2007, с. 447) і Не пожадай дому твого ближнього, ані вола, ані осла, ані жадної річи, котра єсть єго власностію (Шептицький, 2007, с. 524).

Інтертекстуальні ознаки властиві також використанню в посланнях Андрея Шептицького крилатого вислову дім на піску (синонім - diм на скелі) (Матв., 7, 26-27), котрий актуалізовано в Нагірній проповіді і який означає роботу, виконану «непродумано, наспіх, недбало» (Коваль, 2001, c. 185):

Той, щз слухає Христові слова, а не творить їх (Мт. 7, 26), має віру, але мертву, і тому подібний до нерозумного мужа, що збудував свій дім на піску; але й віра жива, себто звершена Божою любов'ю, може, як ми це бачили, більше або менше розуміти. "Чи ж і ви без розуму?» - питає Христос апостолів (Шептицький, 2009, с. 938).

Леся Українка використовує також інтертекстуальні вислови з лексемою дім, запозичені з народнопоетичних текстів та класичної літератури, 
наприклад, Бувай здорова. Дуже міцно цілую тебе і всіх, “хто в тому дому, у веселому» (до Косач О. П. (матері), Ялта, 23.IX (5.X).1897) (у цьому контексті епітет веселий виступає синоніму радісний); Тепер вернімось «з форума до дому» (до Косач О. П. (матері), Ялта, 10 (22).XI.1897).

Деякі означення щодо ядерних лексем концепту дім мають індивідуально диференційований вияв і слугують індикатором особливостей метамови родини Косачів, зокрема колоратив серенький у сполученні з лексемою домик не лише відображає особливості мовлення Лесиної сестри Ольги, а й російськомовний простір побутового спілкування в Києві на початку XX ст.:

А ті болі в грудях, що було тижнями тримали мене в ліжку, ще тоді, як ми «в спреньком домикпь наліво» (йдеться про помешкання в Києві (вул. Стрілецька, 26), де жили старші діти Косачів з матір'ю взимку 1881-1882 та 1882-1883 рр.; 5-річна Ольга описувала тоді цей будинок візникам кількома словами: «серенький домик налево», «серенький домик направо». - прим.) (до Косач О. П. (матері) та Косач О. П. (сестри), Сан-Ремо, 6 (19).III.1902).

До речі, в родинному спілкуванні Косачів саме колоративні означення слугували засобом диференціації будівель у їхньому маєтку: сірий дім / домик (великий дім) і білий / біленький домик (інша назва - новий) (менший, спеціально збудований для Лесі Українки, інакше його ще називали в родині Лесин білий домик, у ньому вона поселилася в кінці вересня 1891 року):

Пишу оие картку, бо папа не схоче ждати, поки допишулиста. Доїхали ми, звичайне, добре. Тут я поміщаюся у великому домі, бо той біленький дуже захаращений річами П[орохова], тай папі, видимо, скучно було б, як би ми вечорі просижували нарізно. В великому домі оказується зовсім нетемно, коли дерева стоять без листу (до Косач О. П. (сестри), Колодяжне, 14 (27).II.1907).

Домівка в Лесі Українки (друга за частотністю вживання лексема) це завжди чуже тимчасове помешкання (і не лише за межами України), про що почасти сигналізують кваліфікативні означення, зокрема літня (домівка) й нова (Сьогодня вони ходили сами пішки в Чукурлар, до моєї літньої домівки, - там їм дуже сподобалось (до Косача П. А., Ялта, 7 (19).IV.1898) i

В Сан Ремо тепер живе (тілько, слава Богу, не зо мною) і п. Нестроєва. Живе вона в санаторії "Rivièra», але вже сьогодня, чую, хоче вибиратися звідти 
і иукає по всьому Сан Ремо собі нової домівки, та не може ніяк знайти (до Драгоманової-Шишманової Л. М., Сан-Ремо, 22.XII.1901 (4.I.1902)).

Синонімом чужого дому в її слововжитку фіксовано також лексему домочок: У всякім разі, коли б і без закладу, а так хоч більшою компанією оселитись тут, найнявши собі домочок, то воно певне не було б дорого (до Косач О. П. (сестри), Хелуан, 18-19.I (31.I-1.II).1910).

Натомість у Андрея Шептицького лексема домівка - демінутив щодо рідного дому. Прикметною ознакою кожної домівки він вважав плекання справжніх, правдивих християнських цінностей і чеснот. А тому органічне порівняння покуті в домівці з престолом у Божому храмі:

Бо й у кожній домівиі поважаєщ і шануєш почесне місие! Водиться, прецінь, між людьми, що як прийдеш до кого, то капелюх чи щапку не кладеш перед самі очі, на стіл, а десь на лаві, а часом і за дверми [...] (Шептицький, 2007, с. 108).

Важливою спільною ознакою для обох комунікантів можна вважати використання лексеми домівка як одного із засобів вияву їхнього емоційного стану, а тому вона має статус емотива.

А отже, концепт дім у мовотворчості й Лесі Українки, й Андрея Шептицького, як засвідчив порівняльний аналіз їхніх текстів, належить до регулятивних явищ. Він зреалізований у трьох основних концептуальних шарах: 1) власне дім; 2) повернення додому; 3) буття вдома і експлікований цілим рядом різнорідних граматично найменувань. Реєстр фіксованих ядерних іменникових лексем в аналізованих текстах - дім, домівка - стверджує спільність і важливість їх використання в мовленні обох комунікантів із виразною диференціацією їхнього функційно-стильового статусу. Диференційною домінувальною ознакою семантичної структури цього номена вважаємо вживання лексеми дім як духової субстанції. Індивідуально окресленими щодо вжитку можна вважати лексеми цього деривативного ряду домик, домочок, дома (імен.) - в Лесі Українки.

Атрибутивні словосполучення зі словом дім в епістолярних текстах і посланнях стверджують виразне протиставлення світської та релігійної комунікації авторів, за винятком інтертекстуальної актуалізації ядерної лексеми. Стилістично диференційовані тексти двох авторів і за особливостями використання регулятива дім як елементів інтертексту. В Андрея Шептицького виявляємо закономірне тяжіння до актуалізації біблійних контекстів, а в Лесі Українки - запозичення з українських 
народнопоетичних текстів або зі світової класики. Спостережено також виразний семантичний зв'язок концепту дім із іншими концептами-регулятивами - родина, Бог, господар, дорога, що може стати об’єктом подальших наукових студій.

\section{Бібліографія}

Андрусів, У. (n.d.). Концепт дім в американській, франиузькій, польській та украӥнській лінгвокультурах (на матеріалі асоціативного експерименту). http://www.ukrainistikkonferenz.slavistik.lmu.de/wp-content/uploads/Dopovid_Andrusiv.pdf

Антонюк, Н. (2012). Мовна репрезентація концепту дім в українській художній прозі XXI cm. http://dspace.onu.edu.ua:8080/handle/123456789/3424

Білодід, I. (Ed.). (1971). Словник украӥнської мови (Vol. 2). Наукова думка.

Болотнова, Н. (2006). Регулятивность. In М. Кожина (Ed.), Стилистический энциклопедический словарь русского языка (2nd ed., pp. 328-331). Флинта.

Болотнова, Н. (2011). О типологии регулятивных структур в тексте как форме коммуникации. Вестник Томского государственного педагогического университета, 2011(3(105)), 34-40.

Воркачев, С. (Ed.). (2007). Лингвокультурный концепт: Типология и области бытования. Парадигма.

Гайда, С. (2016). Национальный стиль как стилистическая категория. Жанры речи, 2016(2), 33-40. https://doi.org/10.18500/2311-0740-2016-2-14-33-40

Галаур, С. (2017). Регулятивність художнього тексту: Функція, категорія, стратегія, теорія. Науковий вісник Міжнародного гуманітарного університету: Серія. Філологія, 30(1), 118-121.

Генеральний регіонально анотований корпус української мови. (n.d.). http://uacorpus.org/

Грінченко, Б. (Ed.). (1907). Словарь украӥнської мови (Vol. 2). Видавництво Української Академії Наук РСР.

Гумецька, Л. (1977). Словник староукраїнської мови XIV-XV cm. (Vol. 1). Наукова думка.

Жайворонок, В. (2006). Знаки української етнокультури: Словник-довідник. Довіра.

Карасик, В., \& Сышкин, Г. (2011). Лингвокультурный концепт как единица исследования. In И. Стернин (Ed.), Методологические проблемы когнитивной лингвистики (pp. 75-80). Воронежский государственный университет.

Коваль, А. (2001). Спочатку було Слово: Крилаті вислови біблійного походження в українсккій мові. Либідь.

Ковальчук, Н. (2016). «Дім»-«поле»-«храм» як екзистенціали української культури. Науковий вісник Національного університету біоресурсів і природокористування України: Серія. Педагогіка, психологія, філософія, 253, 91-96. 
Корпус украӥнської мови. (n.d.). http://korpus.org.ua/

Кочерга, С. (2008). Архетипні мотиви дому і бездомів’я в творчості Лесі Українки. Studia Methodologica, 25, 115-120.

Лебеденко, Ю., \& Василенко, Я. (2013). Вербалізація концепту дім в українській, російській і польській мовах. Studia Ukrainica Posnaniensia, 1, 91-95.

Лебеденко, Ю., \& Василенко, Я. (2016). Національна специфіка концепту дім у польській мові (на матеріалі асоціативного експерименту). Лінгвістичні дослідження, 44, 97-102. https://doi.org/10.5281/zenodo.165079

Монахова, Т. (2010). Типи семантичних деривацій концептів дім і дорога в ідіолекті Валерія Шевчука. Волинь - Житомирщина, 20, 271-280.

Пашкова, Н. (2014). Українська хата: Слово, символ, концепт (на слов'яно-балканському етнокультурному тлі). Вісник Київського національного лінгвістичного університету: Серія. Філологія, 17(1), 121-128.

Піддубна, Н. (2005). Аналітичні найменування релігійних споруд в українській мові. Вісник Львівського університету: Серія білологічна, 34(1), 257-260.

Українка, Л. (2016). Листи 1876-1897. Комора.

Українка, Л. (2017). Листи 1898-1902. Комора.

Українка, Л. (2018). Листи 1903-1913. Комора.

Украӥнський національний лінгвістичний корпус. (n.d.). http://unlc.icybcluster.org.ua/ virt_unlc/

Черкашина, Т. (2016). Концепт «дім» в українській мемуаристиці ХХ століття. Літературний процес: Методологія, імена, тендениії. Філологічні науки, 2016(8), 114-118.

Шевченко, I., \& Давиденко, I. (2012). Дублетний концепт Дім - House / Home в англійській мовній картині світу. Науковий вісник Східноєвропейського національного університету імені Лесі Украйнки: Філологічні науки. Мовознавство, 23, 165-169.

Шептицький, А. (2007). Пастирські послання 1899-1914 pp. (Vol. 1). Видавництво «АРТОС».

Шептицький, А. (2009). Пастирські послання 1918-1939 pp. (Vol. 2). Видавництво «АРТОС».

Шептицький, А. (2010). Пастирські послання 1939-1944 pp. (Vol. 3). Видавництво «АРТОС».

Яворская, Г. (2004). О концепте «дом» в украинском языке. In Сокровенные смыслы: Слово. Текст. Культура (pp. 714-728). Языки славянской культуры.

Янковська, Ж. (2011). Концепт «Дім-Поле-Храм» крізь призму історичного роману Пантелеймона Куліша Чорна рада. Вісник Чернігівського національного педагогічного університету: Серія. Філособські науки, 2011(95), 21-24. 


\section{Bibliography (Transliteration)}

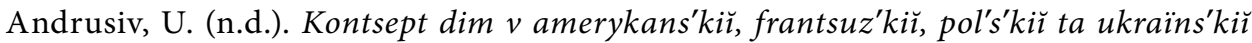
linhvokul'turakh (na materiali asotsiatyvnoho eksperymentu). http://www.ukrainistik -konferenz.slavistik.lmu.de/wp-content/uploads/Dopovid_Andrusiv.pdf

Antoniuk, N. (2012). Movna reprezentatsiia kontseptu dim v ukraïns'kiǔ khudozhniǔ prozi XXI st. http://dspace.onu.edu.ua:8080/handle/123456789/3424

Bilodid, I. (Ed.). (1971). Slovnyk ukraïns'koï movy (Vol. 2). Naukova dumka.

Bolotnova, N. (2006). Reguliativnost'. In M. Kozhina (Ed.), Stilisticheskiǔ éntsiklopedicheskiu slovar' russkogo iazyka (2nd ed., pp. 328-331). Flinta.

Bolotnova, N. (2011). O tipologii reguliativnykh struktur v tekste kak forme kommunikatsii. Vestnik Tomskogo gosudarstvennogo pedagogicheskogo universiteta, 2011(3(105)), 34-40.

Cherkashyna, T. (2016). Kontsept “dim” v ukraïns'kiŭ memuarystytsi XX stolittia. Literaturnyı̆ protses: Metodolohiia, imena, tendentsï: Filolohichni nauky, 2016(8), 114-118.

Gaĭda, S. (2016). Natsional'nyĭ stil' kak stilisticheskaia kategoriia. Zhanry rechi, 2016(2), 33-40. https://doi.org/10.18500/2311-0740-2016-2-14-33-40

Halaur, S. (2017). Rehuliatyvnist' khudozhn'oho tekstu: Funktsiia, katehoriia, stratehiia, teoriia. Naukovyi visnyk Mizhnarodnoho humanitarnoho universytetu: Seriia. Filolohiia, 30(1), 118-121.

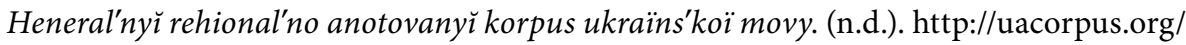

Hrinchenko, B. (Ed.). (1907). Slovar' ukraïns'koï movy (Vol.2). Vydavnytstvo Ukraïns'koï Akademiï Nauk RSR.

Humets'ka, L. (1977). Slovnyk staroukraïns'koï movy XIV-XV st. (Vol. 1). Naukova dumka.

IAnkovs'ka, ZH. (2011). Kontsept “Dim-Pole-Khram” kriz' pryzmu istorychnoho romanu Panteleı̆mona Kulisha Chorna rada. Visnyk Chernihivs'koho natsional'noho pedahohichnoho universytetu: Seriia. Filosofs'ki nauky, 2011(95), 21-24.

IAvorskaia, G. (2004). O kontsepte “dom” v ukrainskom iazyke. In Sokrovennye smysly: Slovo. Tekst. Kul'tura (pp. 714-728). IAzyki slavianskoŭ kul'tury.

Karasik, V., \& Syshkin, G. (2011). Lingvokul'turnyı̆ kontsept kak edinitsa issledovaniia. In I. Sternin (Ed.), Metodologicheskie problemy kognitivnoŭ lingvistiki (pp. 75-80). Voronezhskiĭ gosudarstvennyı̆ universitet.

Kocherha, S. (2008). Arkhetypni motyvy domu i bezdomiv'ia v tvorchosti Lesi Ukraïnky. Studia Methodologica, 25, 115-120.

Korpus ukraïns'koï movy. (n.d.). http://korpus.org.ua/

Koval', A. (2001). Spochatku bulo Slovo: Krylati vyslovy bibliǔnoho pokhodzhennia v ukraïns'kiu movi. Lybid'.

Koval'chuk, N. (2016). "Dim”-"pole"-“khram” iak ekzystentsialy ukraïns'koï kul'tury. Naukovy̌̆ visnyk Natsional'noho universytetu bioresursiv i pryrodokorystuvannia Ukrä̈n: Seriia. Pedahohika, psykholohiia, filosofiia, 253, 91-96. 
Lebedenko, IU., \& Vasylenko, IA. (2013). Verbalizatsiia kontseptu dim v ukraïns'kiŭ, rosiǔs'kiŭ i pol's'kiĭ movakh. Studia Ukrainica Posnaniensia, 1, 91-95.

Lebedenko, IU., \& Vasylenko, IA. (2016). Natsional'na spetsyfika kontseptu dim u pol's'kiǐ movi (na materiali asotsiatyvnoho eksperymentu). Linhvistychni doslidzhennia, 44, 97-102. https://doi.org/10.5281/zenodo.165079

Monakhova, T. (2010). Typy semantychnykh deryvatsiǔ kontseptiv dim i doroha v idiolekti Valeriia Shevchuka. Volyn' - ZHytomyrshchyna, 20, 271-280.

Pashkova, N. (2014). Ukraïns'ka khata: Slovo, symvol, kontsept (na slov'iano-balkans'komu etnokul'turnomu tli). Visnyk Kyïvs'koho natsional'noho linhvistychnoho universytetu: Seriia. Filolohiia, 17(1), 121-128.

Piddubna, N. (2005). Analitychni naĭmenuvannia relihiŭnykh sporud v ukraïns'kiı̌ movi. Visnyk L'vivs'koho universytetu: Seriia filolohichna, 34(1), 257-260.

Sheptyts'kyı̆, A. (2007). Pastyrs'ki poslannia 1899-1914 rr. (Vol. 1). Vydavnytstvo "ARTOS".

Sheptyts'kyı̆, A. (2009). Pastyrs'ki poslannia 1918-1939 rr. (Vol. 2). Vydavnytstvo “ARTOS”.

Sheptyts'kyı̆, A. (2010). Pastyrs'ki poslannia 1939-1944 rr. (Vol. 3). Vydavnytstvo “ARTOS”.

Shevchenko, I., \& Davydenko, I. (2012). Dubletnyı̆ kontsept Dim / House / Home v anhliǐs'kiĭ movniŭ kartyni svitu. Naukovyi visnyk Skhidnoievropers'koho natsional'noho universytetu imeni Lesi Ukraïnky: Filolohichni nauky. Movoznavstvo, 23, 165-169.

Ukraïnka, L. (2016). Lysty 1876-1897. Komora.

Ukraïnka, L. (2017). Lysty 1898-1902. Komora.

Ukraïnka, L. (2018). Lysty 1903-1913. Komora.

Ukraïns'ky̌ natsional'nyı̆ linhvistychnyı̆ korpus. (n.d.). http://unlc.icybcluster.org.ua/virt_unlc/ Vorkachev, S. (Ed.). (2007). Lingvokul'turnyı kontsept: Tipologiia i oblasti bytovaniia. Paradigma. ZHaĭvoronok, V. (2006). Znaky ukraïns'koï etnokul'tury: Slovnyk-dovidnyk. Dovira. 


\title{
The Lexical Regulative dim 'home' in Epistolary Texts by Lesia Ukraïnka and in Andreĭ Sheptyts'kyı̌s Pastoral Letters
}

\author{
Summary
}

This article is devoted to the features of actualisation of one of the most frequent lexical regulatives, which has a distinct archetypal character in the language paradigm of different nations and which is one of the most frequently used concepts in the functional-style system of the Ukrainian language - HOME. The study considers the actualisation of this concept in Ukrainian on the basis of lexicographic sources. It also identifies the main strands of research on the concept HOME which reveal the typological features of its explication in different languages: (1) home as an element of individual style in artistic texts; (2) home as a word stimulus in associative experiments conducted among the youth. The article is the first study investigating the common and distinctive features of the functioning of the lexical regulative dim 'home' in texts created by two well-known authors: Lesia Ukraïnka (epistolary texts) and Andrě Sheptyts'kyı̆ (pastoral letters). The analysis considers key lexemes which verbalise the concept HOME, identifies its core and peripheral nominations, and examines the functional specifics of the contexts of the occurrence of the lexemes dim/doma.

\section{Regulatyw leksykalny dom w tekstach epistolarnych Łesi Ukrainki oraz listach pasterskich Andrzeja Szeptyckiego}

\author{
Streszczenie
}

$\mathrm{W}$ artykule zbadano specyfikę leksykalną jednego z najczęstszych regulatywów, mających wyraźny archetypowy charakter w różnych językach i należący do najczęściej używanych konceptów w systemie funkcyjno-stylowym języka ukraińskiego - DOM. Rozpatrzono reprezentację tego konceptu w języku ukra- 
ińskim na materiale źródeł leksykograficznych; wskazano dwa główne kierunki dotychczasowych badań konceptu DOM ujawniające typologiczne cechy jego eksplikacji w językach narodowych: 1) jako elementu indywidualnego stylu w tekstach artystycznych; 2) jako słowa-klucze w eksperymentach asocjacyjnych wśród młodzieży. Po raz pierwszy przeanalizowano cechy wspólne i cechy odmienne funkcjonowania regulatywu leksykalnego dom w mowie dwóch znanych indywidualności językowych - Łesi Ukrainki (teksty epistolarne) i Andrzeja Szeptyckiego (listy pasterskie); określono podstawowe leksemy, które werbalizują koncept DOM, wyodrębniono nazwy jądrowe i peryferyjne; ustalono specyfikę funkcyjną kontekstów występowania leksemów dim/doma.

Keywords: lexical regulative; concept HOME; epistolary text; pastoral letter; Lesia Ukraïnka; Andreı̆ Sheptyts'kyı̆

Słowa kluczowe: regulatyw leksykalny; koncept DOM; tekst epistolarny; list pasterski; Łesia Ukrainka; Andrzej Szeptycki

(1) Svitlana Bohdan, Lesya Ukrainka Volyn National University, Vinnytsia, Ukraine ORCID: https://orcid.org/0000-0002-4831-2770

Correspondence: bohdan.svitlana@vnu.edu.ua

(2) Tetiana Tarasiuk, Lesya Ukrainka Volyn National University, Vinnytsia, Ukraine ORCID: https://orcid.org/0000-0002-2428-447X

Correspondence: tarasiuk.tania@vnu.edu.ua

Authors' contribution: Concept of the study: first author; data analyses: first and second author; writing the manuscript: first and second author.

The preparation of this article was self-financed by the authors.

Competing interests: The authors have declared that they have no competing interests.

Publication history: Received: 2019-11-03; Accepted: 2021-08-26; Published: 2021-12-20 